\title{
Rtęć w próbkach mieszanin gazowych - przegląd metod pobierania i oznaczania rtęci
}

\section{Mercury in samples of gas mixtures - a review of mercury sampling and determination methods}

\author{
Anna Król, Ewa Kukulska-Zając \\ Instytut Nafty i Gazu - Państwowy Instytut Badawczy
}

\begin{abstract}
STRESZCZENIE: Oznaczanie składu mieszanin gazowych, zwłaszcza tych analitów, które występują jako np. substancje zanieczyszczające główne składniki mieszaniny gazowej, wiąże się bardzo często z koniecznością zatężenia analitu, tak aby można było go ilościowo oznaczyć. Analityka gazowych próbek środowiskowych, w tym próbek powietrza oraz powietrza na stanowiskach pracy, jest trudnym zagadnieniem, co wynika z: konieczności pracy z próbkami o rozbudowanej matrycy i niejednorodnym rozkładzie zanieczyszczeń, z trwałości badanego czynnika oraz z możliwości występowania substancji przeszkadzających (tzw. interferentów) w próbce. Natomiast analiza śladowych komponentów paliw gazowych jest utrudniona ze względu na konieczność pobrania próbki odpowiednio zatężonej, tak aby można było ilościowo oznaczyć te komponenty. W niniejszym artykule przedstawiono przegląd i analizę metod stosowanych do pobierania i oznaczania rtęci w mieszaninach gazowych. Obecnie istnieją znormalizowane metodyki pobierania i oznaczania rtęci przeznaczone dla matryc takich jak powietrze, powietrze na stanowiskach pracy, gazy odlotowe czy gaz ziemny. Są to zarówno metody manualne, jak i w pełni zautomatyzowane. Większość opisanych w literaturze przedmiotu metod składa się z dwóch etapów, tj. etapu pobierania próbki na sorbent stały lub ciekły oraz etapu desorpcji i oznaczenia zawartości rtęci w pobranej próbce z wykorzystaniem przeznaczonych do analizy tego pierwiastka metod. Metodami najczęściej stosowanymi do pobierania próbek rtęci w mieszaninach gazowych są metoda amalgamacji na złocie oraz metody sorpcji na sorbentach proszkowych (takich jak węgiel aktywny, hopkalit, impregnowany żel krzemionkowy), włóknach szklanych, impregnowanych sączkach celulozowych i sorbentach ciekłych (takich jak np. mieszaniny kwasów). Metody desorpcji próbki są zróżnicowane i zależne od materiału, na którym zasorbowano analit, oraz od dobranej metody oznaczania rtęci. Do analizy próbek pod kątem zawartości rtęci stosowane są głównie trzy metody, tj. metoda absorpcyjnej spektrometrii atomowej z zastosowaniem zimnych par (CV-AAS), metoda fluorescencyjnej spektrometrii atomowej z zastosowaniem zimnych par (CV-AFS) oraz metoda spektrometrii masowej z plazmą indukcyjnie sprzężoną (ICP-MS). Należy mieć jednak na uwadze, że chociaż dostępne i stosowane do analizy zawartości rtęci w gazie metody są znormalizowane, to jednak nie są odporne na obecność węglowodorów i siarkowodoru w badanych próbkach. To właśnie te związki najczęściej wymienia się jako substancje przeszkadzające podczas oznaczania rtęci w gazach powyższymi metodami.
\end{abstract}

Słowa kluczowe: metody oznaczania rtęci, rtęć w gazach, oznaczanie rtęci w gazie ziemnym.

ABSTRACT: The determination of the composition of gas mixtures, especially those analytes which exist, for example, as contaminants for the main components of the gas mixture, very often requires the concentration of the analyte so that it can be quantified. The analysis of gaseous environmental samples, including air and air samples at workplaces, is difficult, which results from: the need to work with samples with an extensive matrix and heterogeneous distribution of pollutants, the stability of the analyte and the presence of interfering substances (interferents) in the sample. On the other hand, the analysis of trace components of gaseous fuels is difficult due to the need to collect a suitably concentrated sample so that these components can be quantified. This article provides an overview and analysis of the methods used for the collection and determination of mercury in gas mixtures. Currently, there are standardized mercury collection and determination methodologies dedicated to matrices such as air, workplace air, waste gases or natural gas. These are both manual and fully automated methods. Most of the methods described in the literature on the subject consist of two stages, i.e. the stage of collecting a sample for a solid or liquid sorbent and the stage of desorption and determination of the mercury content in the collected sample using methods dedicated to the analysis of this element. The most frequently used methods for collecting mercury samples in gas mixtures are: the gold amalgamation method and the sorption methods on powder sorbents (such as activated carbon, hopcalite, impregnated silica gel), glass fibers, impregnated cellulose filters and liquid sorbents (such as e.g. acids). The methods of sample desorption are varied and depend on the material on which the analyte has been absorbed and the selected mercury determination method. Three methods are

Autor do korespondencji: A. Król, e-mail:anna.krol@inig.pl

Artykuł nadesłano do Redakcji: 04.08.2002 r. Zatwierdzono do druku: 07.10.2020 r. 
mainly used to analyze samples for mercury content, i.e. the cold vapor atomic absorption spectrometry method (CV-AAS), the cold vapor fluorescence atomic spectrometry method (CV-AFS) and the inductively coupled plasma mass spectrometry method (ICP-MS). However, it should be kept in mind that although the methods available and used for the analysis of mercury content in gas are standardized, they are not resistant to the presence of hydrocarbons and hydrogen sulphide in the tested samples. These are the compounds that are most often mentioned as substances interfering in the determination of mercury in gases using the above-mentioned methods.

Key words: mercury determination methods, mercury in gas, determination mercury in natural gas.

\section{Wstęp}

Rtęć, jako pierwiastek szkodliwy i toksyczny, mający negatywny wpływ na środowisko oraz zdrowie i życie ludzi, od dawna budzi na świecie szerokie zainteresowanie i dyskusje. $\mathrm{W}$ środowisku naturalnym pierwiastek ten występuje w formie metalicznej oraz w postaci związków organicznych i nieorganicznych. Analizując źródła wprowadzania rtęci do środowiska, należy pamiętać, że uwalniana ona jest zarówno w procesach naturalnych, jak i antropogenicznych, co zostało opisane między innymi w dokumentach United Nations Environment Programme (UNEP, 2013) oraz w wielu naukowych publikacjach krajowych (Hławiczka, 2008; Gworek et al., 2013a, 2013b; Król et al., 2014) i międzynarodowych (Ferrara et al., 2000; Loppi, 2001; Nriagu i Becker, 2003; Selin, 2009). Zgodnie z dostępnymi danymi literaturowymi źródła pochodzenia rtęci możemy podzielić na trzy grupy, tj. rtęć pochodzenia naturalnego, rtęć z procesów przemysłowych oraz rtęć z procesów niezwiązanych z działalnością przemysłową człowieka. Rtęć występuje w wodzie i innych cieczach, materiałach stałych (np. glebach, pyłach, proszkach czy skałach) oraz w mieszaninach gazowych (powietrzu, gazie ziemnym, gazach technologicznych). Mając na uwadze szkodliwe właściwości tego pierwiastka, jego dość powszechne występowanie oraz fakt, że rtęć jest jednocześnie stosunkowo reaktywnym pierwiastkiem, zagadnienie dotyczące poprawnego oznaczania rtęci i jej związków występujących w różnych matrycach jest szczególnie istotne.

\section{Metody oznaczania rtęci}

Do oznaczania zawartości rtęci w różnego typu próbkach, w tym w próbkach mieszanin gazowych, powszechnie stosowane są czułe techniki i metody wykrywania oraz oznaczania tego pierwiastka. Wśród nich wymienić należy m.in. metody spektrofotometryczne, woltamperometryczne, atomową spektometrię emisyjną z plazmą wzbudzaną indukcyjnie (ICP-AES) oraz mało popularną analizę aktywacji neutronowej (NAA) (Boszke et al., 2002; Park i Choi, 2002; Jaćimović i Horvat, 2004; Siepak i Boszke, 2004; Filho i do Carmo, 2006; Zhu i Alexandratos, 2007; Boszke, 2009). Przez długie lata najbardziej rozpowszechnioną techniką oznaczania rtęci w próbkach stałych i ciekłych była absorpcyjna spektrometria atomowa z zastosowaniem zimnych par (CV-AAS) (Morita et al., 1995). $\mathrm{W}$ technice tej zasada pomiaru opiera się na zjawisku absorpcji promieniowania o specyficznej długości fali przez wolne atomy metali. Jednak technika ta ma swoje wady, tj. ma ograniczony liniowy zakres kalibracji oraz wykazuje interferencje spektralne wynikające $\mathrm{z}$ absorpcji promieniowania przez obecne w próbce lotne związki organiczne i nieorganiczne (Morita et al., 1995). W związku z tym obecnie coraz częściej do oznaczania rtęci stosowana jest technika fluorescencyjnej spektrometrii atomowej z zastosowaniem zimnych par (CV-AFS) (Morita et al., 1995; Hall i Pelchat, 1999; Li i Wang, 2007; Leopold et al., 2008; Boszke, 2009). Technika ta oparta jest na pomiarze natężenia promieniowania emitowanego (fluorescencji) przez wolne atomy analitu oraz absorpcji promieniowania elektromagnetycznego przy odpowiedniej długości fali. Wzbudzeniu towarzyszy przejście elektronów walencyjnych pomiędzy dozwolonymi poziomami energetycznymi (Boszke, 2009). Fluorescencyjna spektrometria atomowa jest bardzo czułą i selektywną techniką oznaczania rtęci oraz selenu, arsenu i bizmutu w próbkach ciekłych i stałych o zróżnicowanej matrycy. Niewątpliwą zaletą i przewagą CV-AFS nad CV-AAS jest większa czułość, szerszy zakres liniowości oraz mniejsze spektralne interferencje. Techniką analityczną często obecnie stosowaną do oznaczania rtęci jest również spektrometria mas ze wzbudzeniem w plazmie indukcyjnie sprzężonej (ICP-MS). W tej technice wykorzystuje się pomiar intensywności strumienia powstałych w plazmie jonów. Wytworzone jony w plazmie sprzężonej indukcyjnie są następnie rozdzielane za pomocą analizatora mas ze względu na wartość stosunku ich masy do ładunku. Do zalet ICP-MS należą bardzo niskie granice wykrywalności wielu pierwiastków, na poziomie pg/l, uzyskiwane dzięki blisko 100-procentowej wydajności jonizacji w plazmie ICP, duża selektywność i doskonała czułość, które umożliwiają oznaczenie całego spektrum pierwiastków w tym samym czasie, a także określenie stężeń poszczególnych izotopów danego pierwiastka w złożonych matrycach. Wszystkie wymienione instrumentalne techniki analityczne stosowane do oznaczania rtęci wymagają wstępnego przygotowania próbek do analizy oraz użycia odpowiedniej procedury pobrania próbki, tak aby można było oznaczyć stężenie analitu z jak największą dokładnością i precyzją (Agilent Technologies, 2011). Etap pobierania próbek do badań jest jednym z najbardziej newralgicznych etapów każdej metody badawczej. W zależności od rodzaju pobieranej próbki 
(gazowa, ciekła czy stała) stosowane są odpowiednie techniki pobierania próbki reprezentatywnej. Istotnym elementem pobierania próbki jest zachowanie odpowiednich środków ostrożności, które zapobiegają kontaminacji próbek zarówno podczas pobierania, jak i transportu oraz ich przechowywania.

\section{Pobieranie i oznaczanie rtęci w powietrzu}

Sposób pobierania próbek powietrza w celu oznaczenia w nich zawartości rtęci uzależniony jest od tego, jakie formy tego pierwiastka w powietrzu mają być oznaczone. $\mathrm{Z}$ form rtęci występujących w powietrzu największy udział ma rtęć elementarna w postaci gazu (GEM, $\mathrm{Hg}(0))$. Ta forma rtęci jest stosunkowo mało reaktywna i słabo rozpuszcza się w wodzie, może jednak stosunkowo długo utrzymywać się w powietrzu (od 1 miesiąca do 1,5 roku) i w związku z tym jej zanieczyszczenia mogą przemieszczać się wraz z masami powietrza na duże odległości. Bardziej reaktywne i wykazujące zdolność do rozpuszczania się w wodzie są tzw. reaktywne formy rtęci (RGM) oraz rtęć zawieszona na cząstkach pyłu $\mathrm{Hg}(\mathrm{p})$. Te dwie grupy stanowią 1-2\% całkowitej rtęci zawartej w powietrzu i wykazują mniejszą zdolność do przemieszczania się, łatwiej ulegają depozycji i krócej pozostają w atmosferze (1 dzień do 1 tygodnia) (Valente et al., 2007; Pyta, 2010; Pandey et al., 2011). W próbkach powietrza atmosferycznego pobierane i oznaczane są głównie: gazowa forma rtęci metalicznej (GEM) lub całkowita zawartość rtęci gazowej (TGM) oraz rtęć zaadsorbowana na cząstkach pyłu zawieszonego w powietrzu $(\operatorname{Hg}(\mathrm{p}))$.

Podczas pobierania próbek powietrza w celu oznaczenia zawartości rtęci stosowane są czujniki sorpcyjne. Rtęć zawarta w powietrzu sorbowana jest zwykle na złocie. Powierzchnia sorpcyjna złota zwiększana jest poprzez stosowanie bardzo cienkich warstw złotych lub poprzez nanoszenie cienkiego filmu złota na inne materiały sorpcyjne (np. krzemionkę), co zwiększa powierzchnię sorpcyjną użytego sorbentu. Jako materiał sorpcyjny wykorzystywane są również wata szklana, filtry celulozowe, filtry z włókien szklanych, filtry teflonowe oraz ciekłe roztwory sorpcyjne pozwalające na zatężenie próbki do badań (Valente et al., 2007; Pyta, 2010; Pandey et al., 2011). Zestawienie materiałów sorpcyjnych oraz manualnych i automatycznych metod pobierania próbek powietrza pod kątem oznaczania w nich zawartości rtęci przedstawiono w tabeli 1.

Analiza danych przedstawionych w tabeli 1 pokazuje, że opisane w literaturze metody pobierania próbek rtęci z powietrza polegają głównie na sorpcji rtęci lub jej związków:

- na złocie (frakcja GEM - rtęć metaliczna);

- na sorbentach ciekłych lub rurkach zwanych denuderami (tzn. kwarcowe rurki powleczone kwasem, na którym sorbują się reaktywne związki rtęci);
- na filtrach (teflonowych, z włókien z waty szklanej, celulozowych itp.) oraz płuczkach z roztworem pochłaniającym, na których wyłapywana jest rtęć i jej związki zabsorbowane na cząstkach stałych.

Opisane metody to metody manualne oraz zautomatyzowane. Dobór zarówno materiału sorpcyjnego, jak i metody pobierania próbki dokonywany jest z uwzględnieniem takich czynników jak warunki pobierania próbek oraz docelowa metoda analizy chemicznej pobranej próbki pod kątem oznaczenia koncentracji rtęci. Istotnym kryterium doboru materiału sorpcyjnego jest jego odporność na inne związki potencjalnie obecne w badanym powietrzu, niskie tło analityczne i małe opory w powietrzu, a także wytrzymałość mechaniczna (Valente et al., 2007; Pyta, 2010; Pandey et al., 2011). Kolejnym ważnym elementem pobierania próbek powietrza z użyciem materiałów sorpcyjnych jest sam sposób pobierania próbki (czas i szybkość przepływu). W literaturze opisywane jest zagadnienie zafałszowania wyników w sytuacji, gdy zbyt słabo związane z sorbentem związki rtęci są porywane przez strumień powietrza lub odparowują z filtra w czasie prowadzenia poboru próbki (Lu i Schroeder, 1999; O’Driscoll et al., 2003; Pyta et al., 2008).

Natomiast do oznaczenia zawartości rtęci w próbkach powietrza i powietrza na stanowiskach pracy mogą zostać wykorzystane metody opisane w odpowiednich, przeznaczonych do tego celu normach. Zestawienie norm zalecanych do stosowania podczas oznaczania zawartości rtęci w powietrzu oraz powietrzu na stanowiskach pracy zostało przedstawione w tabeli 2.

Należy podkreślić, że normy te zwykle zawierają wytyczne dotyczące: pobierania próbek, warunków ich przechowywania, wstępnej obróbki, ekstrakcji oraz metody oznaczenia analitycznego (Krasińska, 2011).

\section{Pobieranie i oznaczanie rtęci w gazie ziemnym i gazach przemysłowych}

Druga grupa mieszanin gazowych, w których oznaczana jest rtęć, to gaz ziemny oraz gazy przemysłowe (tj. gazy z procesów technologicznych oraz gazy odlotowe). Polskie prawo limituje dopuszczalną zawartość rtęci w gazie ziemnym zarówno w systemie przesyłowym, jak i dystrybucyjnym. Określony prawnie limit wynosi $30 \mu \mathrm{g} / \mathrm{m}^{3}$ rtęci w gazie - dla obu systemów. Zawartość rtęci w gazie ziemnym jest ściśle kontrolowana, zgodnie z Rozporządzeniem Ministra Gospodarki z dnia 2 lipca 2010 r. w sprawie szczegółowych warunków funkcjonowania systemu gazowego (Rozporządzenie Ministra Gospodarki z dnia 2 lipca 2010 r.; Holewa i Szlęk, 2013; Kogut et al., 2018), a sposób kontroli został opisany w polskich normach PN-C-04752:2011 oraz PN-C-04753:2011 (PN-C-04752:2011, PN-C-04753:2011). Ze względu na dopuszczalne zawartości 
Tabela 1. Zestawienie materiałów sorpcyjnych oraz metod pobierania próbek rtęci z powietrza (Valente et al., 2007; Pyta, 2010; Pandey et al., 2011)

Table 1. List of sorption materials and methods of sampling mercury from air (Valente et al., 2007; Pyta, 2010; Pandey et al., 2011)

\begin{tabular}{|c|c|c|}
\hline Forma rtęci & Metoda pobierania próbek & Opis/uwagi \\
\hline \multirow{3}{*}{ GEM/TGM } & Amalgamacja na złocie & $\begin{array}{l}\text { Materiał sorpcyjny - blaszki złote, druciki złote, złoto sorbowane, np. na żelu krzemion- } \\
\text { kowym. } \\
\text { Rekomendowana prędkość pobierania próbki: } 0,05-0,51 / \mathrm{min} \text {. }\end{array}$ \\
\hline & Automatyczny analizator (Tekran) & $\begin{array}{l}\text { Metoda automatyczna, sorpcja rtęci na złotej pułapce, powietrze przepływa przez pułap- } \\
\text { kę z prędkością } 1,51 / \text { min przez około } 10 \mathrm{~min} \text {. } \\
\text { Możliwość pomiaru z prędkością } 1,01 / \mathrm{min} \text { oraz } 10 \mathrm{l} / \mathrm{min} \text {. } \\
\text { Zabsorbowana rtęć jest termicznie desorbowana i analizowana na zintegrowanym detek- } \\
\text { torze CV-AFS. } \\
\text { Czułość metody to około } 0,15 \mathrm{ng} / \mathrm{m}^{3} \text {. }\end{array}$ \\
\hline & Automatyczny analizator (Gardis) & $\begin{array}{l}\text { Metoda automatyczna, sorpcja rtęci na złotej pułapce, powietrze przepływa przez pułap- } \\
\text { kę z prędkością } 1 \text { 1/min przez około } 10 \text { min. } \\
\text { Analizator posiada membranę z PTFE, chroniącą go przed przedostaniem się do niego } \\
\text { cząstek zawieszonych (aerozolu). } \\
\text { Analiza rtęci zachodzi na detektorze AAS. }\end{array}$ \\
\hline \multirow{3}{*}{ RGM } & Komora mgielna $(0,5 \% \mathrm{KCl})$ & $\begin{array}{l}\text { Przez sorbent przepuszczane jest powietrze z prędkością nie większą niż } 12 \mathrm{l} / \mathrm{min} \text {. } \\
\text { Ma ograniczenia, nie może być stosowana w temperaturze poniżej } 0^{\circ} \mathrm{C} \text {. }\end{array}$ \\
\hline & Annular Denuder (powlekany $\mathrm{KCl}$ ) & $\begin{array}{l}\text { Kwarcowe rurki powlekane } \mathrm{KCl} \text {, pobór próbki następuje poprzez przepuszczanie powie- } \\
\text { trza przez denuder z prędkością około } 5 \mathrm{l} / \mathrm{min} \text {. } \\
\text { Analiza zasorbowanej rtęci następuje po termicznej desorpcji w } 500^{\circ} \mathrm{C} \text { na detektorze } \\
\mathrm{CV} \text {-AFS (np. urządzenie Tekran) lub po ekstrakcji rtęci z denudera do roztworu wody } \\
\text { zostaje zredukowana } \mathrm{SnCl}_{2} \text { i poddana analizie na CV-AFS. }\end{array}$ \\
\hline & Tubular Denuder (powlekany $\mathrm{KCl}$ ) & $\begin{array}{l}\text { Kwarcowa rurka powlekana } \mathrm{KCl} \text {, podczas pobierania próbki denuder podgrzewany jest } \\
\text { do temperatury } 45^{\circ} \mathrm{C} \text { w celu uniknięcia kondensacji pary wodnej. Zwykle pracują } 3 \text { de- } \\
\text { nudery równoczasowo. Pobór próbki następuje poprzez przepuszczanie powietrza przez } \\
\text { denuder z prędkością około } 11 / \text { min. Analiza zasorbowanej rtęci następuje po termicznej } \\
\text { desorpcji w } 450^{\circ} \mathrm{C} \text { na detektorze CV-AFS. } \\
\text { Rzadko stosowany ze względu na zalecane niskie przepływy gazu. }\end{array}$ \\
\hline \multirow{7}{*}{$\operatorname{Hg}(\mathrm{p})$} & Rurki z watą szklaną & $\begin{array}{l}\text { Materiał sorpcyjny - rurki o średnicy } 8 \mathrm{~mm} \text { wypełnione watą szklaną. } \\
\text { W celu osiągnięcia zadowalającej czułości metody próbka powinna być pobierana przez } \\
21 \text { godzin z prędkością } 3-4 \text { l/min. }\end{array}$ \\
\hline & $\begin{array}{l}\text { Filtracja z użyciem oprawek typu } \\
\text { filter pack }\end{array}$ & $\begin{array}{l}\text { Najczęściej stosowana z filtrami z włókna szklanego lub kwarcowymi. } \\
\text { Możliwa do zastosowania selekcja rozmiarów cząstek pyłu. }\end{array}$ \\
\hline & Filtry celulozowe & $\begin{array}{l}\text { Materiał sorpcyjny - filtry o średnicy } 47 \mathrm{~mm} \text {, średnicy porów } 0,45 \mu \mathrm{m} \text {, przygotowane } \\
\text { przez wstępną impregnację kwasem. } \\
\mathrm{W} \text { celu uzyskania odpowiedniej granicy detekcji przez filtr powinno zostać przepuszczo- } \\
\text { ne } 8-10 \mathrm{~m}^{3} \text { badanej próbki. }\end{array}$ \\
\hline & Filtry z włókien szklanych & $\begin{array}{l}\text { Materiał sorpcyjny - filtry o średnicy } 47 \mathrm{~mm} \text {, przygotowane przez wstępną impregna- } \\
\text { cję kwasem. } \\
\text { W celu uzyskania odpowiedniej granicy detekcji próbka powinna być pobierana z pręd- } \\
\text { kością } 10 \text { 1/min przez co najmniej } 60 \mathrm{~min} \text {. }\end{array}$ \\
\hline & Filtry teflonowe & Stosowane do oznaczania rtęci całkowitej, w tym fazy gazowej i związanej z pyłem. \\
\hline & Impaktory kaskadowe & Możliwych do pobrania 3-5 frakcji pyłu poprzez zastosowanie otworów o różnej średnicy. \\
\hline & $\begin{array}{l}\text { Płuczki bełkotkowe z roztworem } \\
\text { pochłaniającym }\end{array}$ & Stosowane do oznaczenia rtęci całkowitej, w tym fazy gazowej i związanej z pyłami. \\
\hline
\end{tabular}

rtęci w gazie ziemnym w systemie przesyłowym i dystrybucyjnym oraz właściwości korozyjne rtęci (które mają negatywny wpływ na stan urządzeń wydobywczych, rurociągów i instalacji kopalnianych) gaz pochodzący ze złóż o podwyższonej zawartości rtęci przed wprowadzeniem do systemu gazowniczego musi zostać poddany technologii oczyszczania z rtęci (Lubaś, 1986; Alberta Research Council Inc., 2009; Janocha, 2011; Król et al., 2016). Kontrola poziomu zawartości rtęci w gazie odbywa się zwykle poprzez zastosowanie znormalizowanych procedur oznaczania tego pierwiastka. Zarówno w Stanach Zjednoczonych, jak i w krajach Unii Europejskiej opracowane zostały i wprowadzone do stosowania normy dotyczące pobierania i oznaczania rtęci w próbkach gazów. Zestawienie norm odnoszących się do pobierania i oznaczania zawartości rtęci w gazie ziemnym oraz próbkach gazów przemysłowych przedstawiono w tabeli 3. 
Tabela 2. Zestawienie norm dotyczących oznaczania zawartości rtęci w powietrzu oraz powietrzu na stanowiskach pracy (PN-EN 13211:2006; PN-EN 14884:2010; PN-EN 15852:2010; PN-Z-04332:2006)

Table 2. List of standards for the determination of mercury content in air and air at workplaces (PN-EN 13211:2006; PN-EN 14884:2010; PN-EN 15852:2010; PN-Z-04332:2006)

\begin{tabular}{|c|c|c|}
\hline Numer normy & Nazwa normy & Charakterystyka metody \\
\hline $\begin{array}{c}\text { PN-Z- } \\
\text { 04332:2006 }\end{array}$ & $\begin{array}{l}\text { Ochrona czystości powietrza - Ozna- } \\
\text { czanie par rtęci na stanowiskach pracy } \\
\text { metodą absorpcyjnej spektrometrii ato- } \\
\text { mowej techniką zimnych par }\end{array}$ & $\begin{array}{l}\text { Metoda polega na adsorpcji par rtęci na hopkalicie, wymywaniu zatrzymanego } \\
\text { związku kwasem azotowym(V) i oznaczaniu rtęci w otrzymanym roztworze me- } \\
\text { todą absorpcyjnej spektrometrii atomowej z zastosowaniem techniki zimnych par } \\
\text { (CV-AAS). } \\
\text { Najmniejsze stężenie rtęci, jakie można oznaczyć, wynosi około } 0,003 \mathrm{mg} / \mathrm{m}^{3} \text {. } \\
\text { W celu oznaczenia zawartości par rtęci należy przepuścić do } 40 \mathrm{dm}^{3} \text { powietrza ze } \\
\text { stałym strumieniem objętości, nie większym niż } 1 \mathrm{dm}^{3} / \mathrm{min} \text {. Norma zaleca stoso- } \\
\text { wanie szybkości przepływu } 0,2 \mathrm{dm}^{3} / \text { min. } \\
\text { Próbka pobierana z wykorzystaniem pompki ssącej, wymuszającej przepływ. }\end{array}$ \\
\hline $\begin{array}{c}\text { PN-EN } \\
13211: 2006\end{array}$ & $\begin{array}{l}\text { Jakość powietrza - Emisja ze źró- } \\
\text { deł stacjonarnych - Manualna metoda } \\
\text { oznaczania stężenia rtęci ogólnej }\end{array}$ & $\begin{array}{l}\text { Metoda referencyjna, manualna oznaczania stężenia rtęci ogólnej. } \\
\text { Pozwala na oznaczenie rtęci w zakresie od } 0,001 \mathrm{mg} / \mathrm{m}^{3} \text { do } 0,5 \mathrm{mg} / \mathrm{m}^{3} \text {. }\end{array}$ \\
\hline $\begin{array}{c}\text { PN-EN } \\
14884: 2010\end{array}$ & $\begin{array}{l}\text { Jakość powietrza - Emisja ze źródeł } \\
\text { stacjonarnych - Oznaczanie rtęci cał- } \\
\text { kowitej: automatyczne systemy pomia- } \\
\text { rowe }\end{array}$ & $\begin{array}{l}\text { W normie podano wymagania dla automatycznych systemów pomiarowych zale- } \\
\text { canych do monitoringu rtęci całkowitej }(\mathrm{Hg}) \text {, gdy wielkość emisji gazów jest za- } \\
\text { warta pomiędzy } 0,03 \mathrm{mg} / \mathrm{m}^{3} \text { a } 0,5 \mathrm{mg} / \mathrm{m}^{3}(\mathrm{w} \text { warunkach standardowych). } \\
\text { Norma jest przeznaczona do stosowania dla pomiarów emisji ze spalarni odpa- } \\
\text { dów, w powiązaniu z EN } 14181 \text { i standardową metodą referencyjną EN } 13211 \text {. } \\
\text { Może być też zastosowana do innych procesów, dla których pomiary emisji po- } \\
\text { winny być wykonane z określoną dokładnością. }\end{array}$ \\
\hline $\begin{array}{c}\text { PN-EN } \\
15852: 2010\end{array}$ & $\begin{array}{l}\text { Jakość powietrza atmosferycznego - } \\
\text { Standardowa metoda oznaczania rtęci } \\
\text { gazowej całkowitej }\end{array}$ & $\begin{array}{l}\text { Standardowa metoda oznaczania gazowej rtęci całkowitej (TGM) w powietrzu } \\
\text { atmosferycznym z zastosowaniem absorpcyjnej lub fluorescencyjnej spektrome- } \\
\text { trii atomowej z użyciem zimnych par (CV-AAS lub CV-AFS) oraz absorpcyjnej } \\
\text { spektrometrii atomowej z korekcją tła wg Zeemana (Zeman AAS). } \\
\text { Norma odnosi się do oznaczania rtęci w terenie zurbanizowanym, przemysłowym } \\
\text { lub do oznaczania tła, gdy spełnione są wymagania dyrektywy 2004/107/EC. } \\
\text { Zalecany zakres pomiarowy obejmuje stężenia występujące w powietrzu atmos- } \\
\text { ferycznym od wartości typowych dla tła - poniżej } 2 \mathrm{ng} / \mathrm{m}^{3} \text {, aż do wartości wyż- } \\
\text { szych występujących na terenach przemysłowych. Maksymalny średni dzienny } \\
\text { wynik uzyskiwany w badaniach polowych wynosi } 300 \mathrm{ng} / \mathrm{m}^{3} \text {. }\end{array}$ \\
\hline
\end{tabular}

Metody oznaczania zawartości rtęci w gazie polegają głównie na sorpcji rtęci ze strumienia gazu na złocie lub innym materiale sorpcyjnym (ziarna krzemionki impregnowane jodem, sorbent węglowy lub kwaśny roztwór nadmanganianu pota$\mathrm{su}$ ), a w kolejnym etapie na desorpcji lub mineralizacji zasorbowanej rtęci i pomiarze metodą absorpcyjnej spektrometrii atomowej z generowaniem zimnych par (CV-AAS) lub fluorescencyjnej spektrometrii atomowej techniką generowania zimnych par (CV-AFS). Podstawowym ograniczeniem stosowania scharakteryzowanych w tabeli 3 norm jest obecność w gazie węglowodorów ciekłych oraz wysoka zawartość siarki (PN-EN ISO 6978-1:2007; PN-EN ISO 6978-2:2007; PEI, 2015).

Znormalizowane metody przeznaczone do oznaczania zawartości rtęci w gazie ziemnym pozwalają na oznaczenie rtęci powyżej $0,001 \mu \mathrm{g} / \mathrm{m}^{3}$. Część z nich realizowana jest na aparatach pozwalających na prowadzenie pomiaru in-situ (często on-line). Na rynku dostępne są aparaty przeznaczone do pracy na obiektach, w przypadku których próbka gazu jest pobierana i badana na obiekcie, a których producenci deklarują zgodność pomiarów z normami przeznaczonymi dla badania rtęci w gazie ziemnym (Lumex; Mercury Instruments $\mathrm{GmbH}$,
2008; PEI, 2015). To właśnie dla aparatów, za pomocą których może być analizowana zawartość rtęci in-situ, przeznaczone są polskie normy wymienione w tabeli 3. Normy te dopuszczają jednak zastosowanie procedur, w których etap pobierania próbek gazu przebiega na obiekcie, a już sam pomiar ilości zasorbowanej rtęci - w laboratorium. Jednak prowadzenie analiz poza miejscem pobierania próbek gazu obliguje pobierającego do pobrania próbki tak, aby ilość zasorbowanej rtęci w układzie była właściwa. Zgodnie z zapisami normy (PN-EN ISO 6978-2:2007) sposób pobierania próbki jest właściwy, jeśli ilość rtęci zasorbowana na drugim w szeregu elemencie złotym w układzie pomiarowym stanowi od $10 \%$ do $25 \%$ całkowitej zawartości rtęci oznaczonej w pomiarze. Tylko w takiej sytuacji szybkość przepływu gazu jest dobrze dobrana do ilości rtęci w gazie i można założyć prawidłową efektywność sorpcji par rtęci na złotych elementach sorpcyjnych (PN-C-04752:2011; PN-C-04753:2011; PEI, 2015).

Należy zwrócić uwagę, że podczas oznaczania zawartości rtęci w gazie ziemnym z zastosowaniem metod znormalizowanych ważnymi czynnikami limitującymi prawidłowy pomiar zawartości rtęci w gazie są takie czynniki jak prędkość 
Tabela 3. Zestawienie norm dotyczących pobierania i oznaczania zawartości rtęci w gazach (PN-EN ISO 6978-1:2007; PN-EN ISO 6978-2:2007; PEI, 2015)

Table 3. List of standards for the sampling and determination of mercury content in gases (PN-EN ISO 6978-1:2007; PN-EN ISO 6978-2:2007; PEI, 2015)

\begin{tabular}{|c|c|c|c|}
\hline Numer normy & Nazwa normy & Charakterystyl & letody \\
\hline \multirow{8}{*}{ ASTM D6350 } & \multirow{8}{*}{$\begin{array}{l}\text { Standardowa metoda } \\
\text { analizy próbek na za- } \\
\text { wartość rtęci w gazie } \\
\text { ziemnym z zastoso- } \\
\text { waniem metody spek- } \\
\text { troskopii fluorescencji } \\
\text { atomowej }\end{array}$} & Sposób detekcji & Desorpcja termiczna/CVAFS \\
\hline & & Granica wykrywalności & $0,001 \mu \mathrm{g} / \mathrm{m}^{3}$ \\
\hline & & Liczba analiz dla 1 próbki & 1 \\
\hline & & $\begin{array}{l}\text { Dostępne metody zapewnienia jakości / materiały } \\
\text { odniesienia }\end{array}$ & Brak \\
\hline & & Limit masy rtęci na materiale sorpcyjnym (złoto) & Brak \\
\hline & & Czas pobierania próbki & 4 godziny, limitowany stężeniem rtęci \\
\hline & & Ilość przepuszczanego gazu dla jednej próbki & Do $0,5 \mathrm{~m}^{3}$ \\
\hline & & Możliwość analizy in-situ & Tak \\
\hline \multirow{8}{*}{ EPA Method 30B } & \multirow{8}{*}{$\begin{array}{l}\text { Oznaczanie całkowi- } \\
\text { tej emisji rtęci w fazie } \\
\text { gazowej z elektrow- } \\
\text { ni węglowych z wy- } \\
\text { korzystaniem sorbentu } \\
\text { węglowego }\end{array}$} & Sposób detekcji & $\begin{array}{l}\text { Mineralizacja/CV-AAS } \\
\text { Spalanie CV-AAS }\end{array}$ \\
\hline & & Granica wykrywalności & $0,001 \mu \mathrm{g} / \mathrm{m}^{3}$ \\
\hline & & Liczba analiz dla 1 próbki & 1 \\
\hline & & $\begin{array}{l}\text { Dostępne metody zapewnienia jakości / materiały } \\
\text { odniesienia }\end{array}$ & Tak \\
\hline & & Limit masy rtęci na materiale sorpcyjnym & Brak \\
\hline & & Czas pobierania próbki & Od 8 do 168 godzin \\
\hline & & Ilość przepuszczanego gazu dla jednej próbki & Do $10 \mathrm{~m}^{3}$ \\
\hline & & Możliwość analizy in-situ & Brak \\
\hline \multirow{8}{*}{$\begin{array}{l}\text { PN-EN ISO } \\
6978-1: 2007\end{array}$} & \multirow{8}{*}{$\begin{array}{l}\text { Gaz ziemny - Ozna- } \\
\text { czanie rtęci - Część 1: } \\
\text { Pobieranie próbek rtę- } \\
\text { ci metodą chemisorp- } \\
\text { cji na jodzie }\end{array}$} & Sposób detekcji & Desorpcja termiczna CV-AFS \\
\hline & & Granica wykrywalności & $0,001 \mu \mathrm{g} / \mathrm{m}^{3}$ \\
\hline & & Liczba analiz dla 1 próbki & 1 \\
\hline & & $\begin{array}{l}\text { Dostępne metody zapewnienia jakości / materiały } \\
\text { odniesienia }\end{array}$ & $\begin{array}{l}\text { Tak (jeśli zawartość rtęci na 2. połą- } \\
\text { czonym szeregowo czujniku przekra- } \\
\text { cza } 25 \% \text {, pomiar należy powtórzyć) }\end{array}$ \\
\hline & & Limit masy rtęci na materiale sorpcyjnym & Brak \\
\hline & & Czas pobierania próbki & 4 godziny lub więcej \\
\hline & & Ilość przepuszczanego gazu dla jednej próbki & Od $0,15 \mathrm{~m}^{3}$ do $2,0 \mathrm{~m}^{3}$ \\
\hline & & Możliwość analizy in-situ & Brak \\
\hline \multirow{8}{*}{$\begin{array}{l}\text { PN-EN ISO } \\
6978-2: 2007\end{array}$} & \multirow{8}{*}{$\begin{array}{l}\text { Gaz ziemny - Ozna- } \\
\text { czanie rtęci - Część 2: } \\
\text { Pobieranie próbek rtę- } \\
\text { ci metodą amalgowa- } \\
\text { nia włókna ze stopu } \\
\text { złoto-platyna }\end{array}$} & Sposób detekcji & $\begin{array}{l}\text { Mineralizacja/CV-AAS } \\
\text { Spalanie CV-AAS }\end{array}$ \\
\hline & & Granica wykrywalności & $0,01 \mu \mathrm{g} / \mathrm{m}^{3}$ \\
\hline & & Liczba analiz dla 1 próbki & 1 \\
\hline & & $\begin{array}{l}\text { Dostępne metody zapewnienia jakości / materiały } \\
\text { odniesienia }\end{array}$ & $\mathrm{Nie}$ \\
\hline & & Limit masy rtęci na materiale sorpcyjnym & Brak \\
\hline & & Czas pobierania próbki & 4 godziny lub więcej \\
\hline & & Ilość przepuszczanego gazu dla jednej próbki & Od $0,005 \mathrm{~m}^{3}$ do $2 \mathrm{~m}^{3}$ \\
\hline & & Możliwość analizy in-situ & $\begin{array}{l}\text { Pod warunkiem posiadania aparatu na } \\
\text { obiekcie, analizatory on-line są do- } \\
\text { stępne w sprzedaży }\end{array}$ \\
\hline
\end{tabular}

przepływu, zastosowany sorbent (złoto, żel impregnowany jodem czy też roztwór ciekły nadmanganianu potasu) oraz czynniki przeszkadzające, obecne w gazie. Jak już wspomniano, czynnikami przeszkadzającymi, mogącymi wpływać na jakość wyniku oznaczenia zawartości rtęci, są siarkowodór oraz węglowodory obecne w gazie ziemnym. Dane literaturowe wskazują, że obecność $100 \mathrm{mg}$ benzenu w $1 \mathrm{~m}^{3}$ gazu może powodować zafałszowanie wyniku w postaci zawyżonego sygnału 
dla rtęci odpowiadającego 200 ng rtęci (wynik na detektorze AAS z korektą tła metodą Zeemana) lub nawet $5000 \mathrm{ng} \mathrm{Hg} / \mathrm{m}^{3}$ (wynik w pomiarze bezpośrednim AAS) (Lumex; Mercury Instruments GmbH, 2008; PEI, 2015). Na rynku są jednak dostępne aparaty wyposażone w systemy detekcji fluorescencji atomowej, w przypadku których wpływ węglowodorów na pomiar zawartości rtęci w gazie jest znikomy (np. sygnał Hg na poziomie $0,7 \mathrm{ng} / \mathrm{m}^{3}$ dla benzenu obecnego w próbce na poziomie 100 mg/m³) (PN-C-04752:2011; PN-C-04753:2011; PEI, 2015). Ponadto normy PN-EN ISO 6978 część 1 i część 2 przeznaczone są do oznaczania rtęci w gazie o jakości gazu gazociągowego, czyli teoretycznie już oczyszczonego z nadmiaru zarówno węglowodorów, jak i siarkowodoru (PN-Z-04332:2006; PN-EN ISO 6978-2:2007; Holewa i Szlęk, 2013; Kogut et al., 2018). Należy jednak dodać, że w dalszym ciągu problem z interferentami, a dokładnie mówiąc z siarkowodorem, występuje podczas oznaczania zawartości rtęci w gazie na różnych etapach procesu eksploatacji złoża i intensyfikacji wydobycia, gdy ocenia się potencjał złoża i jakość gazu surowego, jeszcze przed jego oczyszczeniem.

\section{Podsumowanie i wnioski}

Przeprowadzony przegląd i analiza metod pobierania i oznaczania rtęci wykazały, że istnieją znormalizowane metody pobierania i oznaczania zawartości rtęci w powietrzu, powietrzu na stanowiskach pracy oraz $\mathrm{w}$ gazie ziemnym i gazach przemysłowych. Oznaczenie zawartości rtęci w próbkach mieszanin gazowych obejmuje dwa zasadnicze etapy, tj. etap pobierania i zatężenia próbki na sorbentach (stałych i ciekłych) oraz etap analizy pobranego materiału.

Jako materiały sorpcyjne podczas pobierania próbek powietrza stosowane są m.in. złoto, węgiel aktywny, wata szklana, hopkalit, roztwory kwaśne oraz sączki impregnowane kwasami. Natomiast do oznaczania zawartości rtęci w gazie ziemnym wykorzystywane są metody polegające na sorpcji rtęci na złocie, żelu krzemionkowym impregnowanym jodem oraz sorbencie węglowym. Oznaczanie zawartości rtęci w gazie ziemnym może być prowadzone bezpośrednio na obiekcie, jak również w laboratorium. W tym drugim przypadku pobierający musi zapewnić prawidłowe dobranie szybkości przepływu lub wielokrotne pobranie próbek, tak aby można było w jakościowy sposób ocenić zawartość rtęci w gazie. Do analizy próbek mieszanin gazowych pod kątem zawartości rtęci stosowane są głównie: metody absorpcyjnej spektrometrii atomowej z zastosowaniem zimnych par (CV-AAS), metody fluorescencyjnej spektrometrii atomowej z zastosowaniem zimnych par (CV-AFS) oraz metody spektrometrii masowej z plazmą indukcyjnie sprzężoną (ICP-MS). Należy jednak dodać, że w przypadku analizy zawartości rtęci w gazie stosowane metody pobierania próbek i ich analizy nie zawsze są odporne na siarkowodór, który uznawany jest za główny interferent obecny w gazie ziemnym, mogący wpływać na wynik oznaczania zawartości rtęci.

Artykuł powstał na podstawie pracy statutowej pt. Weryfikacja metod oznaczania rtęci $w$ gazie z uwzględnieniem interferentów - praca INiG - PIB na zlecenie MNiSW; nr zlecenia 0093/ GE/19/2001, nr archiwalny DK-4100-0079/2019.

\section{Literatura}

Agilent Technologies, 2011. Successful Low Level Mercury Analysis using the Agilent 7700 Series ICP-MS. <https://www.agilent.com/ cs/library/articlereprints/public/5990_7173EN.pdf> (dostęp: październik 2019)

Alberta Research Council Inc., 2009. Potential Release of Heavy Metals and Mercury from UOG Industry into the Ambient Environment - Literature Review. Final report. October 16.

Boszke L., 2009. Kierunki badań i możliwości analityczne w technice fluorescencyjnej spektroskopii atomowej dla oznaczeń rtęci w próbkach środowiskowych. Wiadomości Chemiczne, 63: 7-8.

Boszke L., Kowalski A., Głosińska G., Siepak J., 2002. Analityczne aspekty oznaczania rtęci całkowitej oraz form fizyczno-chemicznych rtęci w próbkach środowiskowych. Część I. Pobieranie, przechowywanie, zatężanie oraz oznaczanie rtęci całkowitej. Ekologia i Technika, 10(4): 106-112.

Ferrara R., Mozzolai B., Lanzillotta E., Nucaro E., Pirrone N., 2000. Volcanoes as emission sources of atmospheric mercury in the Mediterranean Basin. Science of the Total Environment, 259: 115-121. DOI: 10.1016/s0048-9697(00)00558-1.

Filho N.L.D., do Carmo D.R., 2006. Study of an organically modified clay: Selective adsorption of heavy metal ions and voltammetric determination of mercury(II). Talanta, 68: 919-927. DOI: 10.1016/j.talanta.2005.06.028.

Gworek B., Bemowska O., Dmuchowski W., Szewczyk A., WrzostekJakubowska J., 2013a. Źródła uwalniania rtęci do środowiska - regulacje prawne. Wyd. 1. Monografia IOŚ - PIB, Warszawa. ISBN 978-83-60312-42-1.

Gworek B., Dmuchowski W., Bemowska O., Kucharczyk K., Wrzostek-Jakubowska J., Borzyszkowski J., 2013b. Rtęć w środowisku. Wyd. 1. Monografia IOŚ - PIB, Warszawa. ISBN 978-83-60312-52-0.

Hall G.E.M., Pelchat P., 1999. Comparability of Results Obtained by the Use of Different Selective Extraction Schemes for the Determination of Element Forms in Soils. Water Air Soil Pollutants, 112: 41-53. DOI: 10.1023/A:1005073432015.

Hławiczka S., 2008. Rtęć w środowisku atmosferycznym. Works \& Studies-Prace i Studia nr 73. Wyd. IPIŚ PAN, Zabrze.

Holewa J., Szlęk M., 2013. Ocena jakości gazów palnych. Nafta-Gaz, 6: $450-454$.

Jaćimović R., Horvat M., 2004. Determination of total mercury in environmental and biological samples using k0-INAA, RNAA and CVAAS/AFS techniques: Advantages and disadvantages. Journal of Radioanalytical and Nuclear Chemistry, 259: 385-390. DOI: 10.1023/B:JRNC.0000020905.95715.88.

Janocha A., 2011. Badania procesów korozji w odwiertach o dużej zawartości rtęci. Nafta-Gaz, 3: 171-174.

Kogut K., Smulski R., Szurlej A., 2018. Problem rtęci w eksploatacji i zużyciu gazu ziemnego na tle innych paliw. Przemyst Chemiczny, 6(97): 888-891. DOI: 10.15199/62.2018.6.10. 
Krasińska A., 2011. Doskonalenie metod oznaczania zawartości substancji nieorganicznych w powietrzu na przykładzie par rtęci. Nafta-Gaz, 9: 654-660.

Król A., Krasińska A., Kukulska-Zając E., 2014. Rtęć w środowisku - najnowsze wytyczne związane z gospodarowaniem zasobami rtęci. Chemik, 68(11): 973-978.

Król A., Kukulska-Zając E., Macuda J., 2016. Metody monitoringu i remediacji gruntów zanieczyszczonych rtęcią na terenach przemysłowych. Nafta-Gaz, 8: 626-632. DOI: 10.18668/NG.2016.08.06.

Leopold K., Harwardt L., Schuster M., Schlemmer G., 2008. A new fully automated on-line digestion system for ultra trace analysis of mercury in natural waters by means of FI-CV-AFS. Talanta, 76: 382-388. DOI: 10.1016/j.talanta.2008.03.010.

Li X., Wang Z., 2007. Determination of mercury by intermittent flow electrochemical cold vapor generation coupled to atomic fluorescence spectrometry. Analytica Chimica Acta, 588: 179-183. DOI: 10.1016/j.aca.2007.02.003.

Loppi S., 2001. Environmental distribution of mercury and other traces elements in the geothermal area of Bagnore (Mt Amiata, Italy). Chemosphere, 45: 991-995. DOI: 10.1016/ S0045-6535(01)00028-5.

Lu J.Y., Schroeder W.H., 1999. Sampling and determination of particulate mercury in ambient air: a review. Water, Air and Soil Pollution, 112: 279-295. DOI: 10.1023/A:1005057022001.

Lubaś J., 1986. Rtęć w permsko-karbońskich gazach ziemnych Niżu Polskiego. Prace Instytutu Górnictwa Naftowego i Gazownictwa, 56.

Lumex. Mercury determination in natural gas. $<$ https://www.lumexinstruments.com/applications/mercury-determination-in-natural-gas. php> (dostęp: październik 2019).

Mercury Instruments GmbH, 2008. MMS - Mercury Monitoring System for Natural Gas. <http://www.mercury-instrumentsusa. com/Brochures/MI\%20MMS-NG\%20Brochure.pdf> (dostęp: październik 2019)

Morita H., Tanaka H., Shimomura S., 1995. Atomic fluorescence spectrometry of mercury: principles and developments. Spectrochimica Acta B 50: 69. DOI: 10.1016/0584-8547(94)00116-D.

Nriagu J., Becker C., 2003. Volcanic emissions of mercury to the atmosphere: global and regional inventories. Science of the Total Environment, 304: 3-12. DOI: 10.1016/S0048-9697(02)00552-1.

O'Driscoll N.J., Siciliano S.D., Lean D.R.S., 2003. Continuous analysis of dissolved gaseous mercury in freshwater lakes. Science of the Total Environment, 304: 285-294. DOI: 10.1016/ S0048-9697(02)00575-2.

Pandey S.K., Kim K., Brown R.J.C., 2011. Measurement techniques for mercury species in ambient air. Trends in Analytical Chemistry, 30(6): 899-917. DOI: 10.1016/j.trac.2011.01.017.

Park S.M., Choi H.S., 2002. Sensitized spectrophotometric determination of trace $\mathrm{Hg}$ (II) in benzalkonium chloride media. Analytica Chimica Acta, 459: 75-81. DOI: 10.1016/S0003-2670(02)00103-4.

PEI, Portnoy Environmental, Inc., 2015. The Measurement \& Monitoring of Mercury. In Gas-Phase Hydrocarbon Process Streams. Mercury Management. White Paper 2015. PEI (Mercury \& Chemical Services Group) and EFGS. <http://pei-tx.com/pdf/ The-Measurement-\&-Monitoring-Of-Mercury-In-Gas-PhaseHydrocarbon-Process-Streams.pdf $>$ (dostęp: marzec 2020).

Pyta H., 2010. Metody pomiarów zawartości rtęci w pyle zawieszonym. [W:] Musialik-Piotrowska A., Rutkowski J.D. (red.). Współczesne osiągnięcia w ochronie powietrza atmosferycznego. Materiaty z X Konferencji POL-EMIS 2010. Wyd. PZITS nr 893. ISBN 978-83-921167-9-0.

Pyta H., Grzegorczyk M., Zajusz R., 2008. Wpływ warunków pobierania próbek na wyniki pomiarów stężenia rtęci w powietrzu. [W:] Musialik-Piotrowska A., Rutkowski J.D. (red.). Aktualne problemy w ochronie powietrza atmosferycznego. Materiały z IX Konferencji POL-EMIS 2008. Wyd. PZITS nr 880. ISBN 978-83-921167-6-9.

Selin N.E., 2009. Global Biogeochemical Cycling of Mercury: A Review. The Annual Review of Environment and Resources, 34: 43-63. DOI: 10.1146/annurev.environ.051308.084314.

Siepak J., Boszke L., 2004. Analytical methods in determination of mercury species in environmental samples. An overview. Acta Toxicologica, 12: 87-100.

UNEP, 2013. Global Mercury Assessment 2013: Sources, Emissions, Releases and Environmental Transport.

Valente R.J., Shea C., Humes K.L., Tanner R.L., 2007. Atmospheric mercury in Global Smoky Mountains compared to regional and global levels. Atmospheric Environment, 42: 1861-1873. DOI: 10.1016/j.atmosenv.2006.10.054.

Zhu X., Alexandratos S.D., 2007. Determination of trace levels of mercury in aqueous solutions by inductively coupled plasma atomic emission spectrometry: Elimination of the 'memory effect'. Microchemical Journal, 86: 37-41. DOI: 10.1016/j. microc.2006.09.004

\section{Akty prawne i dokumenty normatywne}

ASTM D6350-14 Standard Test Method for Mercury Sampling and Analysis in Natural Gas by Atomic Fluorescence Spectroscopy. PN-C-04752:2011 Gaz ziemny - Jakość gazu w sieci przesyłowej.

PN-C-04753:2011 Gaz ziemny - Jakość gazu dostarczanego odbiorcom z sieci dystrybucyjnej.

PN-EN 13211:2006 Jakość powietrza - Emisja ze źródeł stacjonarnych - Manualna metoda oznaczania stężenia rtęci ogólnej.

PN-EN 14884:2010 Jakość powietrza - Emisja ze źródeł stacjonarnych - Oznaczanie rtęci całkowitej: automatyczne systemy pomiarowe.

PN-EN 15852:2010 Jakość powietrza atmosferycznego - Standardowa metoda oznaczania rtęci gazowej całkowitej.

PN-EN ISO 6978-1:2007 Gaz ziemny - Oznaczanie rtęci - Część 1: Pobieranie próbek rtęci metodą chemisorpcji na jodzie.

PN-EN ISO 6978-2:2007 Gaz ziemny - Oznaczanie rtęci - Część 2: Pobieranie próbek rtęci metodą amalgowania włókna ze stopu złoto-platyna.

PN-Z-04332:2006 Ochrona czystości powietrza - Oznaczanie par rtęci na stanowiskach pracy metodą absorpcyjnej spektrometrii atomowej techniką zimnych par.

Rozporządzenie Ministra Gospodarki z dnia 2 lipca 2010 r. w sprawie szczegółowych warunków funkcjonowania systemu gazowego (Dz.U. nr 133, poz. 891).

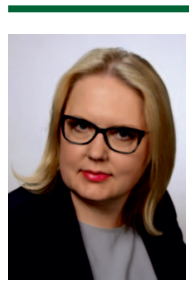

Dr Anna KRÓL

Adiunkt w Zakładzie Ochrony Środowiska Instytut Nafty i Gazu - Państwowy Instytut Badawczy ul. Lubicz 25 A

31-503 Kraków

E-mail: anna.krol@inig.pl

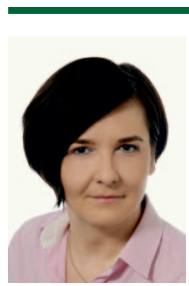

Dr Ewa KUKULSKA-ZAJĄC

Adiunkt; kierownik Zakładu Ochrony Środowiska Instytut Nafty i Gazu - Państwowy Instytut Badawczy ul. Lubicz 25 A

31-503 Kraków

E-mail: kukulska@inig.pl 